\title{
Paideusis
}

\section{A Philosophical Mancunian in Montreal}

\section{Harold Entwistle and Sandra Bruneau}

Volume 19, Number 2, 2010

URI: https://id.erudit.org/iderudit/1071923ar

DOI: https://doi.org/10.7202/1071923ar

See table of contents

Publisher(s)

Canadian Philosophy of Education Society

ISSN

0838-4517 (print)

1916-0348 (digital)

Explore this journal

Cite this document

Entwistle, H. \& Bruneau, S. (2010). A Philosophical Mancunian in Montreal.

Paideusis, 19(2), 69-77. https://doi.org/10.7202/1071923ar

(c) Harold Entwistle, Sandra Bruneau, 2010

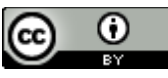

This document is protected by copyright law. Use of the services of Erudit (including reproduction) is subject to its terms and conditions, which can be viewed online.

https://apropos.erudit.org/en/users/policy-on-use/
This article is disseminated and preserved by Érudit.

Érudit is a non-profit inter-university consortium of the Université de Montréal, Université Laval, and the Université du Québec à Montréal. Its mission is to promote and disseminate research.

https://www.erudit.org/en/ 


\title{
A Philosophical Mancunian in Montreal ${ }^{1}$
}

\author{
HAROLD ENTWISTLE (and SANDRA BRUNEAU) \\ Concordia University
}

\section{Early History and War Experience}

Harold Entwistle was born in 1923 in Manchester, England to working class parents. He won a scholarship to grammar school at eleven. Although it was assumed that for economic reasons he would have to leave school at fourteen to work - the legal leaving age, he left school at fifteen when World War II broke out. Like many early leavers from grammar schools, he took an uninteresting job as a junior clerk, and then enrolled in night school courses in commercial subjects, hoping eventually to find something more interesting and with better prospects.

But the war continued and, at 18, he was conscripted into the Royal Tank Corps as a tank gunner. His unit landed in Normandy just after D-day and fought across France, Belgium, Holland, and into Germany. He spent the latter part of 1945 in Germany as part of the occupying forces. In January, 1946, his regiment was posted to perform similar duties in Italy, before being released from the service in early 1947. Living in Italy provided Entwistle a good opportunity to develop a love for the country and an appreciation of its culture. The British Army had set up university-style Formation Colleges in every former theatre of war, in part, to help ease men back into academic life. For three months, he attended the Formation College in Perugia where he studied history, English, geography, and economics. As a result of these academic and travel experiences, he applied for an ex-serviceman's grant to become a teacher.

\section{Teaching Certification and Teaching Experience}

From 1947 to 1949, Harold attended the City of Sheffield Training College, a two-year teachers college. He achieved good academic grades, but felt he had been assessed as a 'B' teacher on school practice. For reasons unknown, grades for practice teaching at that time were not published or revealed to students.

For ten years beginning in 1949, Harold taught school: two years in a secondary modern school where he acknowledges he made beginners' mistakes; then four years in a primary school where he taught all subjects except music; and finally, four years in a newly-established secondary modern school as head of the history department. In that position, he created a syllabus based on H.G. Wells' A Short History of the World (1922). In his Introduction, Wells acknowledges that he wrote the book as an anti-

\footnotetext{
${ }^{1}$ Mancunian: / n. \& adj. * n. a native of Manchester, England. * adj. of or relating to Manchester. [Latin Mancunium Manchester]. The Canadian Oxford Dictionary. Toronto: Oxford University Press, 1998.

(C) Copyright 2010. The authors, Harold Entwistle and Sandra Bruneau, assign to Paideusis the right of first publication and educational and non-profit institutions a non-exclusive license to use this document for personal use and in courses of instruction provided that the article is used in full and this copyright statement is reproduced. Any other usage is probibited without the express permission of the author.
} 
war text, a counter to the 'drum and trumpet history' then allegedly taught in schools. In that postwar decade, it was assumed that educating for peace was possible. Certainly, Entwistle thought so.

\section{Advanced Studies and Lectureships}

When Harold began to teach, he decided to study part-time for a degree in either history or English. At that time, however, Latin or Greek was required as a pre- or co-requisite for a degree in arts. He tried Latin for a few weeks, but found it tedious and unsatisfying. So, he decided, instead, on a degree in economics, specializing in economic history which required two modern languages. Having studied French from age eleven and having spent some time in France during the war, the modern language requirement presented no problem. Having also acquired some Italian while serving in Italy, Harold registered for a course in Italian to complete the requirements. In his view, these experiences underlined for him the value of studying something which appears to have no practical—only intrinsic_value, but which may open doors later to important opportunities. Without his "compulsory" initiation into Italian, it is unlikely that Harold would have embarked on his book on Gramsci, the Italian Marxist whose writings included reflections on education. Harold thinks of these experiences as examples of a "casting-one's-bread-upon-the-waters theory of liberal education"- that is, learning something for its own sake, without knowing exactly why, but sensing that it might open opportunities later in life. In similar fashion, he was able to use the knowledge acquired earlier for his B.Sc. (1953), externally at the University of London in economics, which became the basis for his research and publications on work, leisure, and the economics of schooling.

Following his first degree, Harold took two higher degrees: he completed an M.Ed. as a part-time student while teaching in Manchester, followed by a London External Ph.D. Both degrees were completed English-style_almost entirely through research, a dissertation, and a minimum of coursework. His magistral thesis was entitled, "The Concept of Democracy and its Implications for Education", which he believed to be a better, more original work than his doctoral thesis, "The Concept of Activity in Education". A shortened and popularized version of the M.Ed. thesis was eventually published by Routledge under the title Political Education in a Democracy (1971). Similarly, Methuen published a revised version of his Ph.D. dissertation entitled Child-centered Education (1970). It was in the former text that he formulated the concept of "associational democracy" which anticipated by several decades the currently popular notion that the citizen's most effective democratic activity is exercised mainly in the institutions of civil society.

In 1959, Entwistle was appointed Lecturer in Education at the City of Leeds Training College. Two years later, he became Head of the Department of Education at a new college for mature students, also in Leeds. Both of these posts involved teaching educational theory, supervising school practice, and some administrative work. In 1962, he applied for the position of Lecturer in Education at the University of Manchester since the position's description and requirements seemed a perfect match for him. The head of department had decided that too many of the existing faculty had only pre-war teaching experience in grammar schools. What they needed was a faculty member who had taught school, and had worked with children thought to have learning difficulties.

Harold spent until 1969 in the Department of Education at Manchester where he found time to work on his Ph.D. from the University of London. In addition to teaching and supervising school practice, he supervised research in comparative, secondary, and adult education. Although he was engaged in philosophy of education for his doctorate, there was little opportunity for Harold to teach the subject in Manchester as several of his senior colleagues had been assigned those courses. 


\section{Emigration to Canada and Sir George Williams (now Concordia) University}

Encouraged by a Canadian colleague at Manchester, Harold emigrated to Canada in 1969 to take up a post at Sir George Williams University in Montreal. The position was in comparative education, the discipline Harold had taught and researched while at Manchester, and which was his alternative to teaching philosophy of education. Over several years, Harold developed courses in politics and education. Concordia eventually offered undergraduate and graduate courses in philosophy of education allowing Harold to teach in his primary discipline. Like most scholars who worked in the field, Harold's approach was primarily conceptual and analytical following the lead of Richard Peters and Israel Scheffler. But Harold realized in the early 1980s that the analytical approach might not be the most beneficial to use with students at the introductory level, and so he adopted the historical approach in which he himself had been educated. He assembled his several chapters entitled, "Philosophers on (not of) Education: From Plato to Peters," and distributed them to students as photocopied packages. Each chapter presented an historical person's position on education with emphasis on what seemed to be his main contributions to educational thought. The chapter headings included:

- Plato and the Education of an Elite,

- Machiavelli and the Education of Citizens,

- Rousseau and the Concept of Negative Education,

- John Dewey: Social Education and the Individual,

- Utilitarianism: Education and the Pursuit of Happiness,

- Existentialism: Education and the Tragic View of Life,

- A.N. Whitehead: Transcending Educational Dichotomies,

- Conceptual Analysis: Peters and the Concept of Educational Relevance,

- Philosophers on the Education of Women,

- Postmodernism and Education, and

- Conclusion: Education-An Essentially Contested Concept.

Methuen Publishers accepted Entwistle's manuscript for publication; the company even sent Harold an advance on royalties. Methuen, however, was sold twice in one year and the new publishers sent Harold's manuscript to two outside readers who recommended that it not be published. The circumstances of this rejection deserve elaboration.

The manuscript was dismissed by the two publisher's readers with the following condescending comment: "The trouble with these 'colonials' is that they do not know what is the current state of the discipline; particularly in this case that the historical approach has been out of fashion for decades." Of course, Harold was well aware that the historical approach to philosophy of education was unfashionable. The irony, however, was that Peters, who had earlier dismissed the historical approach, had just published his final book, Essays on Educators (1970), which was a return to the historical approach with chapters on Plato, Dewey, Spencer, Rousseau, and others. Clearly, Entwistle's "colonial ignorance" put him in good company!

\section{Preparation in Philosophy of Education}

Harold traces his first experiences with philosophy-informal and unplanned-to his teen years when he attended local Methodist classes for young men. Traditionally, these classes were conducted like conventional church services with several hymns, prayers, bible readings, and sermons. Because many of the young men were away at the war, attendance was down. Those remaining were few in number, 
and singing hymns was difficult and embarrassing. The minister, Rev. Harry Hindle, one of Harold's most favourite and influential teachers, conducted the class as a discussion group. Harold realized much later that this had been his introduction to the Socratic method: Hindle would begin by posing a question-for example, "What is faith? Hope? Charity?" - and so on each week through a range of moral, theological, and biblical concepts. He would handle the students' responses as Socrates had in his responses to questions about concepts like "justice."

As well, a Lecturer in Education at Leeds, Leo Connell, was an influential instructor who taught Harold educational theory and supervised practice teaching. ${ }^{2}$ T.H.B. (Tom) Hollins, ${ }^{3}$ who was primarily a linguist and educational psychologist, taught philosophy of education at Manchester, and eventually became Harold's M.Ed. supervisor. Hindle, Connell, and Hollins made Entwistle feel like he had something worthwhile and distinctive to say. It was Hollins who, in due course, offered him his first position as an education lecturer at Leeds.

In the army, Harold attended discussion groups whenever possible. He recalls first reading the Republic while attending Formation College in Perugia, Italy. Back in civilian life, too, he engaged with philosophy whenever the opportunity presented itself while in training college and while studying for his economics degree. But apart from occasional courses in subjects like political philosophy, Harold only undertook the formal study of philosophy when he enrolled for his M.Ed. at Manchester in 1953. In the United Kingdom during the 1930s and 1940s, A.N. Whitehead's Aims of Education (1929) was required reading. Harold was impressed by Whitehead's "principle of rhythm in education" which suggests that every successful educational experience must pass through the three stages: romance, precision, and generalization. This tripartite conception seemed successfully to transcend the unnecessary and misleading either/or dichotomies into which much educational theory had become trapped. Whitehead's conception helped Entwistle to resolve to his own satisfaction many of the educational dilemmas he confronted throughout his career. An essay on Whitehead's principle, in fact, forms the appendix to Entwistle's Child-centred Education (1970).

Another required text for the Manchester M.Ed. focused on Plato (categorized as an idealist), Rousseau (a naturalist), and Dewey (a pragmatist). Harold has re-read these writers' works on education many times-indeed, their insights have served as points of reference for over forty years. His other significant discovery while at Manchester was Karl Popper. In one course, moderated by Hollins, a list of texts written by established thinkers was circulated; each student was to select one for a class presentation. When the list reached Entwistle, only one text was left: Volume 1, "The Spell of Plato", from Popper's The Open Society and its Enemies (1945). This was Harold's introduction to Popper and the text provided him with a different perspective on Plato. Until this time, many British academics had generally regarded Plato positively as a liberal educator, but Plato also inspired those who believed in varieties of educational elitism, justifications for the British 11+ examination system, and forms of exclusiveness in education. In due course, Popper's Objective Knowledge (1972) stimulated Entwistle's criticisms of educational radicals who promoted cultural relativism, and criticisms of those who dismissed traditional liberal curricula as "irrelevant high-status knowledge," with emphasis on the "high".

\section{Influential Writers}

Entwistle regards several other writers as greatly influential on his thinking and teaching. For example, Eric Lunzer, a colleague of Entwistle's at Manchester, was an international expert on Piaget and

\footnotetext{
2 Dr. Leo Connell was Principal of the City of Leeds Training College. He gained his doctorate in 1960 from the University of Leeds and was author of A Century of Teacher Training in Leeds 1875-1975 (1994) and Carnegie: A History of Carnegie College and School of Physical Education, $1933-1976$ (1983).

${ }^{3}$ Editor of the influential Aims in Education: The Philosophic Approach. Manchester University Press, 1964.
} 
provoked Entwistle into reading all of Piaget's writings in English, regularly discussing Piaget with him, and motivating Entwistle to write several essays which remained unpublished. One such essay centred on Harold's disagreement with Lunzer about how the concept of "conservation" really works. In another, Harold argued that Piaget's stage analysis is as relevant to adults when learning a new discipline as it is to children to which Piaget's analysis typically is applied.

Entwistle's copy of Gilbert Ryle's The Concept of Mind (1949) is heavily penciled in the margins, partly in response to Ryle's dismissal of Descartes and his notion of the "Ghost in the Machine", but also because of Ryle's important distinction between "knowing how" and "knowing that." Such ideas as these were invaluable to Entwistle in helping him to define the cognitive content of the curriculum, and in discussing "memory" as an objective of schooling, in contrast, for example, to the clichéd notion that "we forget everything we know when we leave the classroom."

Kant's The Metaphysics of Morals (1996) influenced Entwistle's thinking about moral education, as did Richard Hare's The Language of Morals (1952). Kant's neglected essay, "On the saying 'That It May be All Right in Theory but It's No Good in Practice"' was also invaluable to Harold as he considered the relationship between theory and practice in education and in other subjects where theory and practice might collide. The essential Kantian point for Entwistle was that we often misunderstand what theory is, and what it can and cannot do to explain particular practical situations.

In Harold's view, Michael Polyani's notion of "tacit knowledge" from his Personal Knowledge: Towards a post-critical philosophy (1958) and The Tacit Dimension (1967), was a fruitful concept in discussions about memorization and other texts. Harold also valued S.I. Hayakawa's Language in Thought and Action (1978) that explores procedural and substantive issues in education, all of which presuppose the function of language in human thought, communication, and learning.

Most of the texts discussed thus far are not distinctively education texts. In addition to Plato, Rousseau, Dewey, and Whitehead, Harold was also influenced by others who wrote primarily about education. One was G.H. Bantock, Professor of Education at Leicester, a lecturer with a very conservative perspective who became an influential educational theorist. Left-leaning educators were apt to say things like "If Bantock had been trained in philosophy, he would be absolutely formidable," and "Bantock is the one we must really learn to answer." Indeed, Entwistle believes that a good number of his publications were attempts to counter Bantock.

Otherwise, like most educational philosophers at the time, Entwistle was strongly influenced by Richard S. Peters and P.H. Hirst, and, with some reservations, his own theory of liberal education accords with their influential conceptions of education.

Three authors from other fields of study have greatly influenced Entwistle's research. The works of George Bernard Shaw, especially the prefaces, affected Harold's writing style and his religious attitudes. Having first encountered Shaw at the Formation College in Italy, Harold wrote his dissertation for a course in Advanced English Literature on "Religion in the Works of George Bernard Shaw." John Maynard Keynes's General Theory of Employment, Interest, and Money (1936) was compulsory reading for Harold's courses in economics, together with supplementary material about Keynes which added persuasive insights. Ideologically, Harold remains a Keynsian or neo-Keynsian, which has had an impact on his research and publications on education, work and leisure, and the economics of education. He was also a devoted reader of J.K. Galbraith's work, who helped shape his views of socialism. When it first appeared, Galbraith's The Affluent Society (1958) was widely read. Galbraith's observation that in capitalist societies we live in private affluence amidst public squalor was widely quoted as the reason for a dramatic increase in public enterprise. Entwistle admits he was, and continues to be, affected by these views. 


\section{Educational Research}

Entwistle's research has focused on several main themes which, since 1960, have led to five books (one of them translated into Italian and Spanish), sixteen book chapters, and some thirty articles. His research interests follow distinct themes:

- education and its relationship to work and leisure;

- political education and citizenship;

- the relationship between theory and practice;

- working class education and its relationship to adult education; and

- Marxism and education.

Harold has maintained a career-long interest in curriculum, teaching methods, and in educational finance and organization. For each theme, his approach has been to write several papers on the topic, sometimes over long periods of time. These discussions with himself would eventually lead to his own "satisfactory" solutions. For example, his consideration of the relationship of theory with practice has spanned some sixty years, beginning in 1948 with a critical article he wrote for a student magazine, through several chapters in books and magazines, to an chapter essay which may be the definitive chapter for him: "The Place of Theory in the Professional Education of Teachers" in Teaching: Professionalization, Development and Leadership (2008) edited by David Johnson and Rupert Maclean.

Entwistle has never worried that his publications have at times been dismissed, either as not philosophically rigorous, not philosophically up-to-date, or not philosophy at all. Much of his work has been multi-disciplinary in approach and style, partly because of his own education in literature, economics, politics, sociology, and psychology - the latter two of which he learned informally through reading and through his interactions with colleagues. His approach to educational theory was also shaped by the circumstances surrounding his teaching of children. For ten years during the 1950s, he did not teach children who learned easily. Rather, he was assigned to teach classes in which students' attitudes to school were sometimes hostile and the students unruly or potentially unruly. In these circumstances, Harold would commit himself to consider very seriously the practical problems teachers and schools faced.

But many philosophers argue, then as now, that philosophy cannot and should not be prescriptive and practically-oriented. In order to be practical, Harold found that it was necessary for him to step outside a strictly philosophical approach to engage in education problem-solving. Psychological, sociological, economic, historical, and other factors, he reasoned, must be considered along with philosophical analysis. In retrospect, Entwistle recognizes that he used philosophical analysis mainly to address the conceptual issues integral to the practical problems he investigated. For example, in his work/education/leisure research (see his Education, Work and Leisure, 1971), he analyzed ambiguous concepts such as work, labour, vocation, mechanization, automation, and leisure, while drawing on data from economics, history, politics, and cultural studies, all of which were essential in clarifying the work/leisure relationship. Over the years, Harold recognized that some philosophers of education were reluctant to draw upon other disciplines to illuminate educational issues and schooling practices. Many prefer to study philosophy "for its own sake" and to be known as philosophers rather than educators. Even today, many are adamant that they have nothing to say, as philosophers, about practical educational problems. This point, Harold recalls, was strongly made by some prominent philosophers several years ago at a meeting of the British Philosophy of Education Society (PESGB), when other members enquired what philosophy might say about the teaching of reading.

Harold introduced philosophy into his research on education at several different points, and he sees those introductions as beneficial to his work. But he is also aware of the limitations of his approach, which he labels "multi-disciplinary." He recognizes that one's competencies in each of 
several disciplines are likely to be shallower than they would be if one had simply concentrated on a single discipline. On the merits and problems associated with single discipline or multi-disciplinary analyses of education, he thinks a comparison between the "Continental" and "British" positions may well be instructive. In Britain, the narrower a scholar's focus on his discipline, the more prominent he seems to become. On the Continent, Harold observes, this is not necessarily the case. He points to Karl Polanyi who began life as a physicist, became a medical doctor, then an economist, and finally, a philosopher. On one British view, such a sequence of careers is neither possible nor desirable; the belief is that a person cannot, even as a mature scholar, move into completely new and different disciplines and master them sufficiently well to be authoritative.

\section{Research on Antonio Gramsci}

Thirty years after the original publication of his Antonio Gramsci: Conservative schooling for radical politics (1979), Routledge \& Kegan Paul recently decided to re-issue Entwistle's book in a series entitled "Routledge Revivals." The aim of the series is to "draw upon a distinguished catalogue of imprints and authors associated with Routledge, restoring to print books by some of the most influential academic scholars of the last 120 years." 4

People frequently ask Entwistle why he wrote his book on the Italian Marxist Gramsci and he explains it this way. Gramsci was not widely known before the 1970s, but he was a popular subject in academic journals and elite newspapers and magazines. Generally speaking, in the 1970s and 1980s, there were more publications in educational journals from a Marxist perspective than from any other ideological position, and Gramsci was the inspiration for much of this Marxist theorizing. Harold was struck by the contradictions among several Gramsci-inspired writings and by the misuse of the Italian writer by some influential educators for their own purposes. As he explains in his "Introduction", he decided to spend his 1975-1976 sabbatical year in Bristol working to resolve the contradictions between Gramsci and his many commentators. From this, his manuscript on Gramsci emerged.

\section{Retirement Activities}

Having enjoyed life in retirement longer than he had ever expected to, and also committed to the notion that everyone should try to remain intellectually active, Harold decided in 2000 that he needed a fresh reason to get up in the morning. About ten years ago, he concluded that he would never again read or write anything with "school" or "education" in the title. Nor is he a devotee of crossword puzzles - a possible defense by retirees against Alzheimer's. He was persuaded by a former colleague to join the McGill Institute for Learning in Retirement (MILR), a volunteer organization based upon peer learning. There are no paid professional lecturers, and class members present papers and moderate presentations. As a consequence of his involvement in MILR, Harold has written papers on politics, history, literature, art, economics, and other topics. Since 2006, he has also edited the MILR newsletter. As Harold puts it, "Evidently one can escape from philosophy and educational theory if one wishes, but to be rid of scholarship entirely is unthinkable."

\footnotetext{
${ }^{4}$ Routledge has recently informed Harold that it will re-issue two of his other books_Child-centred Education and Political Education in a Democracy-originally published some forty years ago.
} 


\section{References}

Connell, Leo. A Century of Teacher Training in Leeds 1875-1975. Leeds: Leeds Metropolitan University, 1994.

Connell, Leo. Carnegie: A History of Carnegie College and School of Physical Education, 1933-1976. Leeds: Carnegie School of Physical Education and Human Movement Studies, 1983.

Entwistle, Harold. Child-centered Education. London: Methuen, 1970.

Entwistle, Harold. Political Education in a Democracy. London: Routledge \& Kegan Paul, 1971.

Entwistle, Harold. Education, Work, and Leisure. London: Routledge \& Kegan Paul, 1970.

Entwistle, Harold. Antonio Gramsci: Conservative Schooling for Radical Politics. London and Boston: Routledge \& Kegan Paul, 1979.

Entwistle, Harold. "The Place of Theory in the Professional Education of Teachers," Ed. David Johnson and Rupert Maclean. Teaching: Professionalization, Development and Leadership, Festschrift for Professor Eric Hoyle. London: Springer, 2008. 255-62.

Galbraith, John Kenneth. The Affluent Society. Boston: Houghton Mifflin, 1958.

Hare, Richard M. The Language of Morals. Oxford: Oxford University Press, 1972.

Hayakawa, S.I. Language in Thought and Action. New York: Harcourt Brace Jovanovich, 1972/1978.

Kant, Immanuel. The Metaphysics of Morals. Trans. Mary J. Gregor. Cambridge: Cambridge University Press, 1996. Original edition, Die Metaphysik der Sitten. Reprint of the original edition in vol. 4, Werke, Damstadt: WGB, 1797.

Kant, Immanuel. "On the saying 'That It May be All Right in Theory but It's No Good in Practice."' Ed. G. Rubel. Oxford: Clarendon Press, 1963.

Keynes, John Maynard. General Theory of Employment, Interest, and Money. London: Palgrave MacMillan, 1936.

Polyani, Michael. Personal Knowledge: Towards a Post-Critical Philosophy. Chicago: University of Chicago Press, 1958.

Polyani, Michael. The Tacit Dimension. Chicago: University of Chicago Press, 1967.

Peters, Richard S. Essays on Educators. London: Allen \& Unwin, 1970.

Plato. The Republic. Trans. Benjamin Jowett. New York: Modern Library, [s.d.].

Popper, Karl. The Open Society and its Enemies. Vol. 1, "The Spell of Plato". London: G. Routledge, 1945.

Popper, Karl. Objective Knowledge. Oxford: Clarendon Press, 1972.

Ryle, Gilbert. The Concept of Mind. London: Hutchinson's University Library, 1949.

Wells, H.G. A Short History of the World. New York: Macmillan, 1922.

Whitehead, A.N. The Aims of Education and Other Essays. New York: Macmillan, 1929.

\section{Works that have significantly influenced my thinking}

Bantock, G.H. Education in an Industrial Society. London: Faber and Faber, 1963.

Bantock, G.H. Education and Values. London: Faber and Faber, 1965.

Bantock, G.H. Education, Culture, and the Emotions. Bloomington: Indiana University Press, 1968.

Bantock, G.H. Freedom and Authority in Education: A Criticism of Modern Cultural and Educational Assumptions. London: Faber \& Faber, 1970.

Galbraith, John Kenneth. The Affluent Society. Boston: Houghton Mifflin, 1958.

Hare, Richard. The Language of Morals. Oxford: Clarendon Press, 1952.

Hare, Richard. Freedom and Reason. Oxford: Clarendon Press, 1963.

Hayakawa, S.I. Language in Thought and Action. 1972. New York: Harcourt Brace Jovanovich, 1978. Original edition, Language in Action. Chicago: Institute of General Semantics, 1939.

Hirst, Paul H. "Liberal Education and the Nature of Knowledge." Ed. R. Archambault. Philosophical 
Analysis and Education. London: Routledge, 1965. 113-138.

Hirst, Paul H. and Richard Peters. The Logic of Education. London: Routledge, 1970.

Kant, Immanuel. The Metaphysics of Morals. Trans. Mary J. Gregor. 1797. Cambridge: Cambridge University Press, 1996.

Kant, Immanuel. "On the saying 'That It May be All Right in Theory but It's No Good in Practice."” Ed. G. Rubel. Oxford: Clarendon Press, 1963.

Keynes, John M. General Theory of Employment, Interest, and Money. London: Palgrave MacMillan, 1936.

Peters, Richard S. Ethics and Education. London: George Allen and Unwin, 1966.

Peters, Richard S. Authority, Responsibility and Education. London: Routledge, 1973.

Peters, Richard S. Essays on Educators. London: George Allen and Unwin, 1981.

Polyani, Michael. Personal Knowledge: Towards a Post-Critical Philosophy. Chicago: University of Chicago Press, 1958.

Polyani, Michael. The Tacit Dimension. University of Chicago Press, 1967.

Ryle, Gilbert. The Concept of Mind. London: Hutchinson's University Library, 1949.

Shaw, George Bernard. Plays and Prefaces. London: Constable, 1931.

Vygotsky, Lev S. Thought and Language. Trans. E. Hanfmann and G. Vakar. 1934. Cambridge: MIT Press, 1962. 